\title{
Arbitration of Corporate Law Disputes in Joint Stock Companies under Turkish Law: A Comparative Analysis
}

by

Cem Veziroglu*

This study addresses the arbitrability of corporate law disputes and the validity of arbitration clauses stipulated in the articles of association (AoA) of joint stock companies, and compares Turkish law with German and Swiss jurisdictions in particular. While corporate law disputes are considered arbitrable, disputes concerning invalidity of corporate decisions and actions for dissolution are heavily debated. The paper argues that both types of disputes are arbitrable, albeit judicial dissolution requests accommodate practical hurdles. It is also argued that arbitral awards should be granted the erga omnes effect, as long as the interested third parties are provided with the necessary procedural protection. Furthermore, arbitration clauses can be validly stipulated in the AoA of privately beld joint stock companies. However, the binding effect of the arbitration clause in question depends on its legal nature, namely, korporative or formell. Addressing this issue, the paper proposes to adopt a two-step test. Finally, it suggests practicable legislative recommendations and a model arbitration clause in order to enable and facilitate arbitration in corporate law disputes.

Table of Contents

ECFR 2019, 771-806

A. Introduction . . . . . . . . . . . . . . . . . . . . . 772

B. Setting the Scene . . . . . . . . . . . . . . . . . . . . . 773

I. Contractual and Corporate Law Disputes . . . . . . . . . . . . . . . 773

II. Distinctive Characteristics of Corporate Law Disputes . . . . . . . . . 773

III. Distinction between the Issues of Arbitrability and

Contractual Freedom within the AoA . . . . . . . . . . . . . 775

C. From a Comparative Perspective . . . . . . . . . . . . . . . . . . 776

I. German Law . . . . . . . . . . . . . . . . . . . . . . . . . 777

II. Swiss Law . . . . . . . . . . . . . . . . . . . . . . . . . . . . . . . . . . . . . . . . . . . . . . . . . . . .

III. Other Jurisdictions ～. . . . . . . . . . . . . . . . . . . . . . . . 780

D. Arbitrability of Corporate Law Disputes in Turkish Law . . . . . . . . . . 782

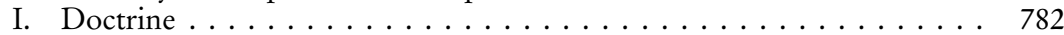

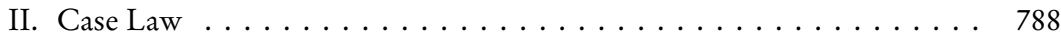

III. Current Position of Turkish Law . . . . . . . . . . . . . . . . 790

* Research assistant, Koç University Law School, Istanbul, Turkey; PhD candidate, University of Istanbul, Istanbul, Turkey. 
E. Place of the Arbitration Clause: AoA or SHA? . . . . . . . . . . . . . . . 790

F. Validity of Arbitration Clause Provided in the AoA . . . . . . . . . . . . . . 791

I. Consent to Arbitration . . . . . . . . . . . . . . . . . . . . . . . . . 792

II. Written Form Requirement . . . . . . . . . . . . . . . . . . . 802

G. Conclusion and Proposals . . . . . . . . . . . . . . . . . . . 803

\section{A. Introduction}

The resolution of disputes by arbitration rather than litigation in national courts has been frequently preferred due to several advantages. These include the ability to select arbitrators who have expertise in the subject matter of the dispute; the flexibility, pace, and confidentiality of the proceedings; the impartiality and finality of the award; and the near global reach of enforcement by virtue of the $1958 \mathrm{New}$ York Convention (Convention). Considering its increasing importance in the international arena and its potential for generating income, many jurisdictions have been adapting their legislation to be in conformity with arbitration, hence encouraging its widespread employment. As a contracting state to the Convention, Turkey has enacted pro-arbitration legislation and established its intent to become a regional arbitration venue by founding the Istanbul Arbitration Center on 1 January 2015. Within this context, Milletlerarası Tabkim Kanunu (International Arbitration Code) No. 4684 (IAC) was enacted in accordance with the UNCITRAL Model Law on International Commercial Arbitration, as was Milletlerarası Özel Hukuk ve Usul Hukuku Hakkinda Kanun (Code Regarding Private International and Civil Procedure Law) No. 5718, and Hukuk Mubakemeleri Kanunu (Civil Procedure Code) No. 6100 (CPC). ${ }^{1}$

The availability of arbitration in corporate law disputes is significant not only for making Turkey a regional arbitration center, but also for incentivizing national and foreign investments, as it decreases potential risks for investors. Accordingly, whether such disputes can be settled by arbitration appears to be a factor influencing investment decisions. However, arbitrating corporate law disputes in joint stock companies entails a series of legal challenges. The present enquiry therefore tries to shed light upon the position of Turkish law in this regard, to identify the problems, and to suggest practicable solutions. The paper addresses both domestic and international arbitral proceedings governed by the CPC and IAC, respectively.

1 For the general framework of international commercial arbitration in Turkey, see Zeynep Derya Tarman, International Commercial Arbitration in Turkey, in: Tuğrul Ansay/Eric C. Schneider (ed.), Introduction to Turkish Law, 2nd ed., 2014, p. 245-250. 
Section 'B' explains the key concepts referred to throughout the paper and the distinctive characteristics of corporate law disputes. Section ' $D$ ' deals with the arbitrability of corporate law disputes, while the place of the arbitration clause and the validity of arbitration clauses provided in the articles of association (AoA) of joint stock companies are tackled in Sections ' $E$ ' and ' $F$ '. A comparative analysis with a functional perspective is conducted throughout the paper, while Section ' $\mathrm{C}$ ' surveys recent developments in various jurisdictions with a special emphasis on German and Swiss jurisdictions.

\section{B. Setting the Scene}

\section{Contractual and Corporate Law Disputes}

Corporate disputes, in a broad sense, are split into two categories: contractual and statutory (also referred to as 'institutional', 'intra-corporate' or 'korporativ') disputes. While both categories concern the rights of shareholders, directors and other stakeholders with respect to each other and the company, they diverge in terms of the legal basis of the claim to be asserted. And while contractual disputes originate from agreements, such as shareholders' agreements (SHA), joint-venture agreements and share purchase agreements, statutory disputes arise from rights granted by law, the AoA of the company and corporate decisions. It follows that the claims peculiar to corporate law, such as annulment of general assembly resolutions, actions for corporate dissolution and liability of directors or the parent company give rise to statutory disputes, which are referred to as 'corporate law disputes' throughout this paper.

\section{Distinctive Characteristics of Corporate Law Disputes}

Contractual disputes concerning joint stock companies do not feature any legal challenges with respect to this research. These are considered arbitrable ${ }^{2}$ and tackled like any other commercial agreements under Turkish law. ${ }^{3}$ However, although there is strong commercial interest in arbitrating corporate law

2 In this study the term "arbitrability" indicates the question of whether the subject matter of the dispute is capable of being settled by arbitration, which is referred to in literature as "objective arbitrability". For the distinction between subjective and objective arbitrability see Julian D.M. Lew/Loukas A. Mistelis/Stefan Kröll, Comparative International Commercial Arbitration, 2003, para. 9.35 et seqq.

3 For SHAs see Burak Huysal, Milletlerarası Ticari Tahkimde Tahkime Elverişlilik, 2010, p. 294; Tolga Ayoğlu, Sermaye Şirketleri Özelinde Şirketler Hukuku Uyuşmazlıklarının Çözümünde Tahkim, 2018, p.226. For share purchase agreements see ibid., p. 289; 
disputes, the issue is unsurprisingly debated due to certain characteristics of the joint stock company as a legal entity.

Firstly, corporate law disputes do not involve only the interests of the parties to a contract, but also those of shareholders, directors, employees, creditors, auditors and even the public. The fact that a broader spectrum of interests are affected in corporate law disputes can be seen as incompatible with the contractual nature of arbitration. ${ }^{4}$ For instance, general assembly resolutions bind all shareholders, even those who were actually opposed to the resolution in question, and those who enter the company thereafter. Accordingly, a decision regarding the invalidity of a general assembly resolution also binds the parties who are not involved in the dispute. Again, the winding-up of a company may be an obvious example of effects exceeding the parties to the dispute (erga omnes effects), as suppliers, creditors and employees are affected as well as shareholders and directors of the company in question. However, arbitration is private in essence. Indeed, an arbitral award may, in principle, be enforced only between the parties to a dispute (inter partes effect). ${ }^{5}$ However, this problem can be solved by granting an erga omnes effect to arbitral awards, while requiring certain safeguards to protect the interests of third parties affected by these proceedings.

Secondly, specific procedural rules pertaining to corporate law disputes are prescribed as mandatory legal provisions in order to protect the interests of third parties. For example, in actions for the annulment of general assembly resolutions, the case is not heard until the term of litigation expires, so as to consolidate all the claims filed by shareholders; and the court may ask the claimant to provide collateral for potential damages of the respondent company. Furthermore, certain statutory provisions may explicitly confer exclusive jurisdiction to a specific local court in order to protect economically weaker groups, such as tenants, consumers, and employees. Although the exclusive jurisdiction of a local court and the non-arbitrability of a dispute are distinct legal questions, they are closely linked in terms of legal policy. ${ }^{6}$ Indeed, the Turkish

Yargitay (Turkish Court of Appeals), 11. Civil Division, 4 May 2010, Case No. 2010/ 1129, Decision No. 2010/4904.

4 Stavros L. Brekoulakis, On Arbitrability: Persisting Misconceptions and New Areas of Concern, in: Loukas A. Mistelis/S Stavros L. Brekoulakis (ed.), Arbitrability: International and Comparative Perspectives, 2009, para. 2.46-2.52.

5 The prima facie incompatibility of erga omnes effects of a dispute with the contractual nature of arbitration is also observed within the context of claims pertaining to the validity of industrial property rights. See M. Polat Kalafatoğlu, L'Arbitrabilité En Matiére De Propriété Industrielle: Étude en droit de l'arbitrage international, 2018, para. 339-383.

6 The exclusive competence of a local court in relation to foreign national courts does not necessarily exclude arbitration. For French law see Jean-Baptiste Racine, L'Arbitrage Commercial International et l'Ordre Public, 1999, p. 48-51; for Belgian law see Olivier 
Court of Appeals (TCA) tends to reject the arbitrability of certain disputes concerning rental, consumer, and employment agreements, with a view to protecting the weaker party. ${ }^{7}$ Correspondingly, since minority shareholders and creditors are generally deemed weaker vis-à-vis the controlling shareholders and/or the board of directors, their right of action cannot be restricted. Yet asserting a claim before an arbitral tribunal, rather than a local court, would not necessarily restrict their right of action.

Last but not least, according to the traditional - and nearly abandoned - approach, the notion of 'public order' (ordre public sociétaire) ${ }^{8}$ may appear to be a barrier to parties submitting their dispute to arbitration, because the issues governed by mandatory legal norms fall outside the scope of arbitration. ${ }^{9}$ Considering that Turkish corporate law mainly involves mandatory norms, unlike the law of obligations which is based primarily on contractual freedom, ordre public sociétaire can be seen as an impediment to arbitration. Nonetheless, the existence of mandatory norms cannot be a reason for non-arbitrability per se, because arbitral tribunals may - and should - apply these norms, just as local courts do.

\section{Distinction between the Issues of Arbitrability and Contractual Freedom within the AoA}

The arbitrability of corporate law disputes is often confused with contractual freedom within the AoA of a joint stock company; these are two distinct issu-

Caprasse, Les Sociétés et L'Arbitrage, 2012, p. 123 et seqq. For Swiss law see Ramon Mabillard/Robert Briner, in: Heinrich Honsell/Nedim Peter Vogt et al. (ed.), Basler Kommentar Internationales Privatrecht, 3rd ed., 2013, Art. 177, para. 12; for Turkish law see Huysal (fn. 3), p. 257 et seq.

7 For rental agreements, see: Yargitay (TCA), 3. Civil Division, 2 December 2004, 2004/ 13018-13409. However, the TCA confirmed the arbitrability of a dispute regarding action for evacuation, where both parties were merchants (Yargitay (TCA), 11. Civil Division, 16 December 2004, 2004/5413-12656). For consumer agreements, see: Yargitay (TCA), 13. Civil Division, 25 September 2006, 2006/7789-12275. For employment agreements, see: Yargitay (TCA), 9. Civil Division, 26 May 2008, 2008/10997-12660 (https:// www.kazanci.com, last accessed 10 August 2018). Also, see Cemal Şanl//Emre Esen/Inci Ataman-Figenmeşe, Milletlerarası Özel Hukuk, 6th ed., 2018, p. 646 et seq.; Ziya Akıncı, Milletlerarası Tahkim, 4th ed., 2016, p. 74; Huysal (fn. 3), p. 128-143.

8 In the context of joint stock company law, the term "public order" infers the mandatory rules and principles applicable to joint stock companies regardless of whether these norms originate from statutes or case law.

9 See the authors mentioned in Pilar Perales Viscasillas, Arbitrability of (Intra-) Corporate Disputes, in: Loukas A. Mistelis/Stavros L. Brekoulakis (ed.), Arbitrability: International and Comparative Perspectives, 2009, para. 14-18. 
es. It is one matter to address whether providing an arbitration clause in an AoA concerning certain types of disputes is permissible under corporate law. The arbitrability of such disputes however is to be dealt with separately.

The non-arbitrability of a corporate law dispute concerns the enforceability of an arbitration clause as applied to such a dispute, whereas the general validity or enforceability of said arbitration clause is not affected. ${ }^{10}$ Therefore, an arbitration clause stipulated in the AoA of a joint stock company can only be enforced in respect to arbitrable disputes. In contrast, if a particular corporate law dispute is non-arbitrable, the arbitration clause is not enforceable, regardless of whether it was stipulated in the AoA or SHA. Yet there may be cases where an arbitration clause cannot be included in the AoA, as the relevant rules of corporate law applicable to the AoA in question do not permit it, although the dispute is in fact arbitrable.

Since a debate regarding the validity of arbitration clauses provided in the AoA would be meaningful with respect to only arbitrable disputes, an analysis should follow these steps: (i) whether the dispute in question is arbitrable; (ii) whether the arbitration clause in question can be validly inserted into the AoA under corporate law; (iii) whether the parties to the dispute are bound by the arbitration clause. Accordingly, this paper primarily addresses the arbitrability problem, and then discusses the validity and the binding effect of arbitration clauses in the AoA of joint stock companies incorporated in Turkey. Prior to passing on to such an analysis, it would be helpful to review the recent developments in various jurisdictions, and thus, understand the current trends in arbitration of corporate law disputes.

\section{From a Comparative Perspective}

Various jurisdictions have adopted specific legal provisions that allow arbitrating corporate disputes and/or providing an arbitration clause in the AoA or by-laws of joint stock companies. Since Turkish corporate law is heavily influenced by Swiss and German law, the principles developed in the case law and legislation of these jurisdictions are to be attached particular importance. Still, other jurisdictions may also set an example and provide practical solutions in this regard.

10 Gary B. Born, International Commercial Arbitration, 2nd ed., 2014, p. 836; Brekoulakis, (fn. 4), para. 2.63-2.64. 


\section{German Law}

Corporate law disputes are generally considered arbitrable in German law, whereas the discussion in the doctrine and case law centers on disputes regarding the validity of general assembly resolutions. ${ }^{11}$ Although the principle of Satzungsstrenge found in $\$ 23 / 5$ of Aktiengesetz (German Stock Corporation Act) is mostly considered an impediment to stipulating an arbitration clause in the AoA of joint stock companies ${ }^{12}$, the arbitrability and validity problems have been resolved in case law with respect to partnerships, limited partnerships and limited liability companies.

In 1996, the German Federal Supreme Court held that disputes regarding the validity of general assembly resolutions are arbitrable. The Federal Court stated that both claims for annulment and declaratory judgment for the nullity of general assembly resolutions were subject to parties' consent, as the general assembly may revoke a previous decision with a new decision. Furthermore, the Federal Court clarified that the exclusive jurisdiction of the local court designated by law does not exclude arbitration, and that the shareholders' irrevocable right of action does not hinder arbitration, provided that the arbitral procedure offers protection mechanisms equivalent to those of legal provisions. Moreover, it was also held that a company is bound by the arbitration clause stipulated in its own AoA, even if it did not participate in the conclusion of the AoA as a party. However, the Federal Court concluded that the dispute at hand could not be arbitrated because the arbitral award would not have had an erga omnes effect, as each shareholder's right to be heard would not have been respected in an arbitration proceeding based on the arbitration clause in question. $^{13}$

11 For the general acceptance of the arbitrability of corporate law disputes, see Manfred Born/Nima Ghassemi-Tabar/Burkhard Geble, Münchener Handbuch des Gesellschaftsrechts, vol. 7, 4th ed., 2015, $\$ 146 \mathrm{mn} .1-4$. For the discussion about the arbitration of the invalidity of general assembly decisions, see Christian Borris, "Die Schiedsfähigkeit gesellschaftsrechtlicher Streitigkeiten in der Aktiengesellschaft", Neue Zeitschrift für Gesellschaftsrecht 2010, 481, 481 et seq.

12 Karsten Schmidt, "Neues Schiedsverfahrensrecht und Gesellschaftsrechtspraxis", Zeitschrift für das gesamte Handels- und Wirtschaftsrecht 1988, 265, 282; Jens Koch, in: Uwe Hüffer/Jens Koch (ed.), Aktiengesetz, 13th ed., $\$ 246$ mn. 18-19; Thomas Dörr, in: Gerald Spindler/Eberhard Stilz (ed.), Aktiengesetz, 3rd ed. 2015, $\$ 246$ mn. 10; Uwe Hüffer/Carsten Schäfer, in: Wulf Goette/Mathias Habersack/Susanne Kalss (ed.), Münchener Kommentar zum Aktiengesetz, vol. 4, 4th ed., 2016, \$246 mn. 33. Cf. authors mentioned in fn. 16.

13 Bundesgerichtshof (Federal Supreme Court), 29 March 1996 - II ZR 124/95, Entscheidungen des Bundesgerichtshofes in Zivilsachen 132, 278. 
In 2009, the Federal Court held that the arbitration clause in the AoA of a $\mathrm{GmbH}$ concerning the validity of general assembly resolutions is valid, provided that the protections and the opportunity of shareholders to participate in the proceedings comparable to those in national court proceedings are respected. Moreover, the Federal Court renounced its standpoint with regard to the inter partes effect of arbitral awards and applied $\$ 248 / 1$ of Aktiengesetz, which establishes an erga omnes effect of national court decisions, mutatis mutandis to the arbitral award. The Federal Court specified the prerequisites and minimum standards of an arbitration clause to be stipulated in an AoA in order for an arbitral award to have an erga omnes effect: (i) a unanimous vote is required for inclusion of such a clause in the AoA; (ii) all shareholders should be provided with an opportunity to participate in the arbitral proceedings; (iii) participating shareholders should be granted a say in the appointment of arbitrators, unless selected by an impartial body; and (iv) consolidation of actions must be ensured in order to prevent contradictory judgments. ${ }^{14}$ In 2017, the Federal Court confirmed these requirements relating to partnerships and limited partnerships. ${ }^{15}$

As regards joint stock companies, the Federal Court has not yet delivered a judgment on the arbitrability of corporate law disputes. However, the discussion in the doctrine focuses on contractual freedom within the AoA. While most authors consider the principle of Satzungsstrenge as a barrier to inclusion of an arbitration clause in the AoA of German joint stock companies, it is also asserted that the said principle is to be applied in a more permissive manner for privately held joint stock companies. ${ }^{16}$ Following the Federal Court's judgment in 2009, 'DIS-Supplementary Rules for Corporate Law Disputes 09' and 'DIS-Model Clause for Corporate Law Disputes 09' were published by the German Arbitration Institution [Deutsche Institution für Schiedsgerichtsbarkeit e.V('DIS')] and entered into effect as of 15 September 2009. The rules and the model clause are

14 Bundesgerichtshof (Federal Supreme Court), 6 April 2009, II ZR 255/08, Entscheidungen des Bundesgerichtshofs in Zivilsachen 180, 221.

15 Bundesgerichtshof (Federal Supreme Court), 6 April 2017, I ZB 23/16, Zeitschrift für Wirtschaftsrecht 2017, 1024.

16 Walter Bayer, Empfehlen sich besondere Regeln für börsennotierte und für geschlossene Gesellschaften?, in: Gutachten E zum 67. Deutschen Juristentag, 2008, p. 108; Diana Bechte-Horbach, Das Schiedsverfahren bei innergesellschaftslichen Streitigkeiten von Kapitalgesellschaften, 2015, p. 56-60; Christian Duve/Philip Wimalasena, in: KarlHeinz Böckstiegel/Stefan Kröll/Patricia Nacimiento (ed.), Arbitration in Germany: The Model Law in Practice, 2nd ed. 2015, p. 938-940; Martin Beckmann, Statutarische Schiedsklauseln im deutschen Recht und internationalen Kontext, 2007, p. 86 and authors mentioned therein. Cf. the authors mentioned in fn. 12, who represent the prevailing view in doctrine, only allow the conclusion of individual arbitration agreement with each shareholder following the lines of the case law on limited liability companies. 
drafted in accordance with the Federal Court's 2009 decision. Between 2010 and 2018 , a total of 40 arbitration proceedings relating to corporate law disputes have been filed before the DIS, being subject to these rules (www.disarb.org).

\section{Swiss Law}

Considering that Switzerland has been one of the leading arbitration venues worldwide, Swiss scholars show a highly positive attitude towards the arbitrability of corporate law disputes. ${ }^{17}$ The debate over disputes concerning challenging corporate decisions and actions for dissolution concentrates on the principle of sole obligation in joint stock companies. ${ }^{18}$ Based on the fact that the Swiss Federal Court characterizes the nature of an arbitration agreement as merely procedural, rather than relating to substantive law, it is widely accepted that the principle of sole obligation is not a barrier against arbitration, because arbitration clauses do not alter shareholders' substantive rights and obligations. ${ }^{19}$

It appears that the pro-arbitration approach in Swiss law has also been reflected in legislative activities with a view to put an end to the debate on the validity of arbitration clauses provided in the AoA. In fact, Article 697n of the Swiss Draft Code of Obligations (Draft), dated 23 November 2016, provides that an arbitration clause may be validly incorporated in the AoA of a joint stock company. ${ }^{20}$ The Draft explicitly states that such an arbitration clause binds the company, its board members and shareholders. Furthermore, Article 704 of the Draft sets a quorum of at least two-thirds of the voting rights and

17 Peter Forstmoser/Arthur Meier-Hayoz/Peter Nobel, Schweizerisches Aktienrecht, 1996, p. 111; Peter Böckli, Schweizer Aktienrecht, 4th ed., 2009, p. 2302; Gabrielle Kaufmann-Kobler/Antonio Rigozzi, International Arbitration: Law and Practice in Switzerland, 2015, para. 3.47; Antonio Monti, Arbitration and Corporate Law in: Antonio Monti/Francesco Trezzini/Francesco Wicki (ed.), Three Essays on International Commercial Arbitration, 2003, p. 104.

18 Art. 680/1 Swiss Code of Obligations (equivalent to Art. 480/1 Turkish Commercial Code).

19 In this view, see Dieter Gränicher (fn. 6), para. 67; Monti (fn. 17), p. 86; cf. Benjamin Büchler/Hans Caspar von der Crone, "Die Zulassigkeit statutarischer Schiedsklauseln”, Schweizerische Zeitschrift für Wirtschafts- und Finanzmarktrecht 3 (2010), 259, 263. For the discussion regarding the question of whether the arbitration agreement is procedural or substantial in nature in Swiss law, see Monti (fn. 17), p. 67-72. In Turkish law, see Hakan Pekcantez/Ali Yeşilırmak, in: Hakan Pekcanıtez/Ali Yeşilırmak (ed.), Pekcanitez Usûl Medeni Usûl Hukuku, 15th ed., 2017, p. 2596-2599.

20 Feuille Fédérale (Federal Gazette) 2017, 625 (https://www.admin.ch/opc/fr/federalgazette/2017/625.pdf, last accessed 10 August 2018). 
an absolute majority of the nominal value of shares represented at the relevant general assembly meeting. The preamble to the Draft states that this amendment aims to clear up doubts by providing a legal basis for the insertion of arbitration clauses in AoAs. Moreover, it is confirmed, once again, that disputes on corporate dissolution, the liability of board members, and the validity of general assembly resolutions are arbitrable. ${ }^{21}$

Since Turkish corporate law is under the influence of Swiss and German laws, it can be assumed that eventually a more liberal approach is likely to be adopted over time. However, the issue is at the intersection of corporate law and arbitration law, and thus, differences in the arbitration rules of the relevant countries are not to be ignored. For instance, Turkish law adopts free disposition of the subject matter of dispute as the criterion of arbitrability for both domestic and international arbitration, like Swiss law does for domestic arbitration. ${ }^{22}$ However, whether the claim relates to economic interests is the criterion adopted for international arbitration in Swiss law, and for both domestic and international arbitration in German law. ${ }^{23}$

\section{Other Jurisdictions}

In Italian law, the problems posed by arbitration clauses stipulated in the AoA of privately held companies are addressed with the enactment of the Legislative Decree of 17 January 2003 No. 5 (Decree) Articles 34-37.24 Pursuant to the Decree, an arbitration clause in the AoA binds the company and all shareholders, as well as board members, liquidators and internal auditors. Arbitration clauses can be inserted into the AoA with at least the approval of two thirds of the voting rights represented in the general assembly meeting. Furthermore, if inserted by an amendment of the AoA, dissenting or absent shareholders have the right to exit the company within 90 days from the passing of the general assembly resolution amending the AoA.${ }^{25}$ Moreover, equal participation of the interested parties is ensured through the requirement that arbitration clauses must provide that all members of the arbitral tribunal be appointed by an im-

21 Feuille Fédérale (Federal Gazette) 2017, 353, 494 (https://www.admin.ch/opc/fr/ federal-gazette/2017/353.pdf, last accessed 10 August 2018).

22 For Turkish law, see Art. 1/4 International Arbitration Code and Art. 408 Civil Procedure Code. For Swiss law, see Art. 354 Swiss Civil Code of Procedure.

23 For Swiss law, see Art. 177 Swiss Federal Code on Private International Law. For German law, see $₫ 1030$ German Code of Civil Procedure.

24 Diego Corapi, “Arbitration and Company Law in Italy", European Company Law 2015, 154, 155-157. Pursuant to Article 34 para. 1 of the Decree, companies listed on a stock exchange cannot introduce arbitration clause in their AoA.

25 Decree Art. 36 para. 6. 
partial third party, as well as the necessary safeguards in the event that such a third party fails to do so. It is estimated that more than 70 per cent of Italian companies and cooperatives include an arbitration clause. ${ }^{26}$

In Brazilian law, Corporations Law No. 6.404/76 of 15 December 1976 Article 109/3 (amended by Law No. 10.303 of 31 October 2001) expressly provides that an arbitration clause may be stipulated in the AoA. Although categorically recognizing the validity of arbitration clauses found in the AoA, the law was not clear on whether shareholders who either expressly voted against the adoption of the arbitration clause or acquired shares thereafter would also be bound by the clause. ${ }^{27}$ Following the inclusion of Article 136-A in the Corporations Law in 2015, all shareholders are now bound by the arbitration clause stipulated in the AoA, and an appraisal right is granted to dissenting shareholders.

French Commercial Code Article L721-3 states that commercial disputes are arbitrable, and it is accepted that both contractual and corporate law disputes fall within this provision..$^{28}$ Furthermore, an arbitration clause provided in the AoA binds all shareholders, even those who dissented or acquired a share after the inclusion of the arbitration clause. ${ }^{29}$

In Spanish law, Arbitration Act No. 60/2003 of 23 December 2003 Article 11 bis provides that in order to insert an arbitration clause into the AoA, the general assembly resolution must be taken by at least two-thirds of the capital. Moreover, the law clearly provides that it is possible to challenge registered corporate decisions by arbitral award. ${ }^{30}$

In Russian law, Articles 33 and 225.1 of Commercial Procedural Code of the Russian Federation were amended by Federal Law No. 409-FZ dated 29 September 2015. As of 1 September 2016, arbitration of corporate law disputes are deemed arbitrable with certain limitations and exceptions. ${ }^{31}$ For instance, disputes concerning insolvency, right to call a general assembly meeting, squeezeouts, acquisition of joint stock company shares of more than 30 per cent are expressly considered non-arbitrable.

26 Viscasillas (fn. 9), para. 14.13.

27 Christos Ravanides, "Arbitration Clauses in Public Company Charters: An Expansion of the ADR Elysian Fields or a Descent into Hades?”, The American Review of International Arbitration 2007, 371, 439-440.

28 Caprasse (fn. 6), p. 684-692; Racine (fn. 6), p. 88; Monti (fn. 17), p. 104.

29 Caprasse (fn. 6), 696-698.

30 Viscasillas (fn. 9), para. 14.4-14.15.

31 Prior to such legislation, nearly all kinds of corporate law disputes were considered nonarbitrable. See Alan Redfern/Martin Hunter et al., Redfern and Hunter on International Arbitration Law, 6th ed., 2015, para. 2.158; Mikhail Ivanov/Inna Manassyan, Russia, in: James H. Carter (ed.), The International Arbitration Review, 7th ed., 2016, p. 437. 


\section{Arbitrability of Corporate Law Disputes in Turkish Law}

There is no statutory rule in Türk Ticaret Kanunu (Turkish Commercial Code) No. 6102 (TCC) as to which corporate law disputes are arbitrable. It follows that general rules of arbitrability apply to these kinds of disputes. In Turkish law, the issue of arbitrability is regulated in the same way for both international and domestic arbitration proceedings. ${ }^{32}$ Accordingly, disputes relating to "rights in rem over an immovable property in Turkey" and those arising from issues "not subject to parties' consent" are non-arbitrable. It is almost unanimously held that an issue being subject to parties' consent means that parties may freely dispose of the matter in dispute by way of settlement. ${ }^{33}$ This civil law notion of 'free disposition' can either be explicitly precluded by a statutory provision or impliedly barred by public policy considerations embedded in the relevant jurisdiction's private law foundations. Considering the lack of an explicit statutory norm with respect to the arbitrability of corporate disputes under Turkish law, the views adopted in doctrine and principles developed in case law may offer valuable guidance for this study.

\section{Doctrine}

During the period of the former Turkish Commercial Code No. 6762 (Former TCC), the vast majority of the doctrine accepted that corporate law disputes were, in principle, arbitrable. ${ }^{34}$ This view holds good for the TCC that entered into force on 1 July $2012 .{ }^{35}$ It is, however, argued by certain authors that dis-

32 Respectively in Art. 1/4 IAC and Art. 408 CPC (see also Convention Articles II/1 and IV/2.(a)).

33 Şanlı/Esen/Ataman-Figenmeşe (fn. 7), p. 645-646; Yavuz Alangoya/Kamil Ylldırm/ Nevhis Deren-Yıldırım, Medeni Usûl Hukuku Esasları, 2009, p. 601; Baki Kuru/Ramazan Arslan/Ejder Yılmaz, Medeni Usul Hukuku, 2014, p. 783; Pekcanıtez/Yeşilırmak (fn. 19), p. 2636. For impacts of the notion "public order" upon arbitrability see Brekoulakis (fn. 4), para. 20-22; Kalafatoğlu (fn. 5), para. 243-244.

34 Hayri Domaniç, Anonim Şirketler Hukuku ve Uygulaması TTK Şerhi II, 1988, p. 230; Reha Poroy/Ünal Tekinalp/Ersin Çamoğlu, Ortaklıklar ve Kooperatif Hukuku, 12th ed., 2010, para. 731; Arslan Kaya, Anonim Ortaklıkta Pay Sahibinin Bilgi Alma Hakk1, 2001, p. 331-332; Mehmet Bahtiyar, Anonim Ortaklık Anasözleşmesi, 2001, p. 209211; Mehmet Helvacı, Anonim Ortaklık Genel Kurul Kararlarının İptali Davalarının Tahkim Yargılamasına Uygunluğu Üzerine Düşünceler, in: Erol Ulusoy/Aslı Yıldırım (ed.), II. Uluslararası Özel Hukuk Sempozyumu “Tahkim”, 2009, p. 190; Huysal (fn. 3), p. 292-310.

35 Burçin Yıldırım, Anonim Ortaklıkta Şirket İçi Uyuşmazlıkların Milletlerarası Tahkim Yoluyla Çözümlenmesi (LLM Thesis, Galatasaray University 2012), p. 29-39; Rauf Karasu, Anonim Şirketlerde Emredici Hükümler İlkesi, 2nd ed., Ankara 2015, p. 173-174; 
putes relating to the validity of corporate decisions and to corporate dissolution are non-arbitrable for the reasons that will be further discussed below.

Before dealing with these controversial types of disputes, it must be noted that while conducting a comparative analysis one must pay the utmost attention to the arbitrability criteria adopted in relevant jurisdictions. Despite the fact that Turkish company law is under the influence of Swiss and German law, arbitrability criteria adopted in Turkish law differs from both. For instance, it is argued that disputes relating to economic interests, such as refund of unjust profit distribution, financial rights of board members, request for default interest, and penalty due to capital subscription, are arbitrable, whereas disputes relating to the validity of corporate decisions, insolvency, and dissolution are nonarbitrable. ${ }^{36}$ Basing the distinction on whether the dispute in question relates to economic interests seems to be inspired by Swiss law, which applies the 'economic interests' criterion to international arbitration proceedings. ${ }^{37}$ However, Turkish law refers to the notion of 'free disposition' while determining the arbitrability of a dispute, unless it relates to rights in rem over an immovable property in Turkey. Therefore, the sole criterion to be considered for corporate law disputes in Turkish law is free disposition of the matter in dispute. Furthermore, even annulment of a general assembly resolution for capital increase may result in return of the payment for capital and decrease of the company's capital, which clearly concerns economic interests. Likewise, dissolution or insolvency of the company may lead to distribution of corporate assets. Therefore, it may be misleading to classify the disputes concerning the validity of corporate decisions, insolvency, and dissolution into the group of disputes that do not relate to economic interests. ${ }^{38}$

Ayşe Şahin, Anonim Ortaklığın Haklı Sebeple Feshi, 2013, p. 373; Ayoğlu (fn. 3), p. 8097.

36 Babtiyar (fn. 34), p. 211; Karasu (fn. 35), p. 173; Pekcanttez/Yeşilirmak (fn. 19), p. 2637.

37 Article 177 Swiss Federal Code on Private International Law.

38 In German and Swiss law, the distinction between claims involving pecuniary and nonpecuniary interests has lost significance for corporate law disputes, since pecuniary interests cover almost all disputes. For Swiss law see Monti (fn. 17), p. 98-99; Tetiana Bersheda, "Les Clauses d'Arbitrage Statutaire en Droit Suisse", Association Suisse de l'Arbitrage Bulletin 2009, 691, 710-715; Philippe Bärtsch, "Consent” in Sports Arbitration: Which Lessons for Arbitrations Based on Clauses in Bylaws of Corporations, Associations, etc.?", Association Suisse de l'Arbitrage Special Series Nr. 41 (2014), 95, 113. For German law see Duve/Wimalasena (fn. 16), p. 931; Harm Peter Westermann, "Schiedsgerichte in kapitalgesellschaftsrechtlichen Streitigkeiten", Zeitschrift für Unternehmens- und Gesellschaftsrecht 2017, 1, 42; Markus S. Rieder/Richard Kreindler, in: Richard Kreindler/Reinmar Wolff/Markus S Rieder (ed.), Commercial Arbitration in Germany, 2016, para. 2.59. 


\section{Validity of General Assembly Resolutions}

The debate on the arbitrability of corporate law disputes is mostly observed within the context of challenging the validity of general assembly resolutions. Yet there is an apparent trend in Turkish legal doctrine, in harmony with the expanding scope of arbitration in various jurisdictions, towards accepting these disputes as arbitrable. As the pioneer of the conservative wing of the doctrine, Morog $\breve{l} u^{39}$ regards such disputes as non-arbitrable for the following reasons: (i) specific procedural rules, such as pending of the case until the term of litigation expires and consolidation of all the actions filed before the court, prevent arbitration; (ii) jurisdiction of the court in the place of the company's registered office is exclusive; (iii) the dispute cannot be settled among the parties and is, hence, not freely disposable; and finally, (iv) an arbitral award cannot be granted an erga omnes effect.

Certain authors suggest that a distinction should be made based on the content of the general assembly resolution. ${ }^{40}$ According to this approach, the dispute is deemed arbitrable if the resolution in question pertains to a matter subject to the parties' consent. For instance, annulment of a general assembly resolution that puts the company into liquidation cannot be submitted to arbitration, while a decision for dividend distribution can be arbitrated.

Another view adopts a distinction based on the type of the remedy claimed, regardless of the content of the resolution in question. This view distinguishes the actions of annulment from declaratory actions for nullity/inexistence. ${ }^{41} \mathrm{It}$ is therefore suggested that the claim to annul a general assembly resolution is arbitrable, whereas the action for declaratory judgment for the nullity/inexistence of such a resolution is non-arbitrable. According to this view, the request for declaratory judgment for nullity/inexistence is not compatible with arbitration, since such an action can be filed by any interested party, and thus, third parties can intervene in the case.

A more liberal interpretation of the doctrine affirms that both the claim for annulment and the declaratory judgment for the nullity/inexistence of general

39 Erdoğan Moroğlu, Anonim Ortaklıkta Genel Kurul Kararlarının Hükümsüzlüğü, 8th ed., 2017, p. 305-306.

40 Mehmet Taş, Türk Hukukunda Anonim Şirket Genel Kurul Kararlarının İptali Davalarının Milletlerarası Ticari Tahkimde Görülmesi (LLM Thesis, University of Istanbul 2007), p. 51-54; Ylldırum (fn. 35), p. 60.

41 Huysal (fn. 3), p. 320-322. 
assembly resolutions are subject to parties' consent, and hence arbitrable. ${ }^{42}$ Kirca states that interested third parties, such as creditors, bondholders and regulatory authorities, are not bound by the arbitration clause found in the AoA or SHA, while leaving the door open to the debate on the extension of arbitration agreements to such persons. Ayoğlu, on the other hand, distinguishes the arbitrability issue from problems connected with specific procedural rules and the impact of arbitration upon third parties. He suggests that statutory provisions concerning procedural rules pertaining to the validity of general assembly resolutions should apply to arbitral proceedings qua 'directly applicable rules' of Turkish corporate law. Moreover, the author indicates that the statutory rule found in TCC Article 450 granting an erga omnes effect upon local court decisions for the invalidity of general assembly resolutions should apply mutatis mutandis to arbitral awards. ${ }^{43}$

In my view, disputes concerning the invalidity of general assembly resolutions are subject to parties' consent, and thus arbitrable. First, the claimant and the respondent may freely conclude the case by way of settlement ${ }^{44}$ or acceptance of the claim, provided that the general assembly confers upon the board such authorization. ${ }^{45}$ Secondly, jurisdiction of the court in the place of the company's registered office does not exclude arbitration, but only establishes the exclusive competence in relation to foreign national courts. ${ }^{46}$ Third, mandatory

42 İsmail Kırca/Feyzan Hayal Şehirali Çelik/Çă̆lar Manavgat, Anonim Şirketler Hukuku, vol 2/2, Genel Kurul Kararlarının Hükümsüzlügü, 2016, p. 229-233 and p. 277; Ayoğlu (fn. 3), p. 108-118.

43 Ayoğlu (fn. 3) 110-112. The author alternatively suggests that the arbitration clause may be formulated so as to implement the mandatory procedural rules by either incorporating or referring to them. Helvacı opines that claims to annul general assembly resolutions are subject to parties' consent, and hence arbitrable, but also suggests that the mandatory procedural rules applied to this type of action effectively prevent arbitration, unless the arbitration clause in question complies with these rules, Helvact (fn. 34), p. 200-202.

44 For annulment of general assembly resolutions, see Helvacı (fn. 34), p. 200.

$45 \operatorname{Kirca}$ (fn. 42), p. 229 fn. 532, p. 253 and p. 277, adopts affirmative approach for both annulment and nullity claims. Moroğlu (fn. 39), p. 360-364, argues that the general assembly may also revoke its previous resolution. If the general assembly can revoke its decision, it can also delegate the board to accept the case a fortiori and thus let the court annul its decision.

46 Exclusive jurisdiction in terms of international civil procedure law does not necessarily exclude arbitration. See Huysal (fn. 3), p. 257-258. For Swiss law see Mabillard/Briner (fn. 6), Art. 177, para. 12. Pursuant to Regulation (EU) No 215/2012 on jurisdiction and the recognition and enforcement of judgments in civil and commercial matters (Regulation) Art. 24/2, the court of the seat has exclusive jurisdiction with regard to disputes concerning the validity of constitution and corporate decisions, as well as the nullity or the dissolution of companies. However, the Regulation does not exclude arbitration (see the Preamble of the Regulation, para 12; Viscasillas (fn. 9), para. 14-23). 
procedural rules regarding a certain type of dispute do not prevent submitting such dispute to arbitration. Relevant procedural rules are to be applied by arbitral tribunals as 'directly applicable rules' of Turkish corporate law. In order to avoid such a problem, parties can stipulate their procedural rules as equivalent to the TCC in their arbitration clause, or they can incorporate by reference the procedural rules set out in the TCC, as well as the set of rules for corporate law disputes published by an arbitration institute. ${ }^{47}$ And finally, arbitral awards regarding disputes over the invalidity of general assembly resolutions should benefit from the erga omnes effect granted to national courts by TCC Article 450 , provided that the third parties ${ }^{48}$ are protected. ${ }^{49}$

\section{Corporate Dissolution}

Arbitrability of disputes concerning corporate dissolution is another controversial area. Different views can be grouped into three categories. While one view completely rejects the arbitrability of requests for corporate dissolution on the grounds that these are not subject to the parties' consent and are closely linked with the law of persons ${ }^{50}$, the opposing view affirms their arbitrability without exception. ${ }^{51}$ Another view distinguishes between the cases of voluntary and involuntary dissolutions, and argues that only the former type of disputes are arbitrable. ${ }^{52}$

47 It is, therefore, advisable that the prominent arbitration institutes publish their own arbitration rules for corporate law disputes.

48 The non-shareholder third parties are not bound by the clause in the AoA, unless they have consented to it. However, their rights to action and/or intervention in the case are confined solely to requests for declaratory judgment for nullity; hence, they cannot claim annulment of general assembly resolutions. Their right of action in the former type of disputes does not per se affect the arbitrability of the dispute. However, this may render arbitration of the dispute at hand ineffective, if an interested third party raises her claim before a local court, because the severance of cases based on the same grounds of action is not possible.

49 This solution is already accepted in German case law, see text to fn. 13-15.

50 Ayoğlu (fn. 3), p. 145-147. Pursuant to Article 367/2 Civil Procedure Code a judicial decision regarding law of persons cannot be enforced until it becomes a definitive judgment. Ayoğlu therefore suggests that arbitral awards dissolving a legal entity cannot be enforced, since arbitration lacks an appellate procedure.

51 Ylldırm (fn. 35), p. 64. For Swiss law see Monti (fn. 17), p. 104; Forstmoser/Meier-Hayoz/Nobel (fn. 17), p. 834; Philipp Habegger, Die Auflösung der Aktiengesellschaft aus wichtigen Gründen, 1996, $\$ 19$ mn. 64 et seqq.

52 Babtiyar (fn. 34), p. 211; Huysal (fn. 3), p. 327. Involuntary dissolutions are comprised of ipso jure dissolution and judicial dissolution cases prescribed in TCC Art. 529-531. A joint stock company is dissolved ipso jure i) upon expiry of the period specified in the AoA, ii) if the object of the company is attained or becomes unattainable or iii) in the 
The issue is particularly contested within the context of the right to request corporate dissolution for just causes stipulated in TCC Article 531. This is a remedy provided for oppressed minority shareholders in joint stock companies. Certain authors suggest that this type of action cannot be adjudicated by arbitrators, because (i) action for dissolution relates to public policy, (ii) the local court designated by TCC has exclusive jurisdiction, and (iii) the dispute is not subject to parties' consent. ${ }^{53}$ In contrast, it is argued that such disputes are subject to parties' consent, and thus, arbitrable ${ }^{54}$, whereas Şabin subjects the arbitrability to the condition that the claimant minority must be granted the option to apply to either a local court or to arbitration..$^{55}$ Still, it must be noted that optional/asymmetrical arbitration clauses are considered invalid under Turkish law, because the parties' intent to arbitrate must be explicitly stated and the jurisdiction of local courts must be excluded. Therefore, leaving the door open for the jurisdiction of local courts by way of an optional arbitration clause is seen as a ground for lack of consent to arbitration. ${ }^{56}$

In my view, disputes regarding corporate dissolution are arbitrable regardless of whether they are voluntary or not. Firstly, joint stock companies can be dissolved by a general assembly resolution at any time. It follows that corporate dissolution is subject to parties' (shareholders) consent, and thus, any dispute relating thereto is arbitrable. Secondly, the fact that corporate dissolution pertains to the law of persons does not per se prevent arbitration, since arbitration does not lack of a judicial review, albeit with a limited scope. ${ }^{57}$ An arbitral award is definitive and final, and therefore can be enforced, unless have been set aside. Moreover, disputes regarding the invalidity of corporate decisions fall

event of realization of any one of the causes of dissolution stipulated in the AoA (Art. 529 Turkish Commercial Code). Judicial dissolution cases are dissolution for lack of mandatory organs and dissolution for just causes, set out respectively in Articles 530 and 531 Turkish Commercial Code. However, Huysal concludes that disputes regarding dissolution for just cause are arbitrable, whereas other disputes over involuntary dissolution are inarbitrable (Huysal (fn. 3), p. 327).

53 Emel Hanağası, "Anonim Ortaklığın Haklı Sebeple Feshi Davasının Medenî Usûl Hukuku Perspektifinden Değerlendirilmesi”, Banka ve Ticaret Hukuku Dergisi 32 (2016), 199, 232-233. Tekinalp and Erdem argue for the same approach without indicating any reason or justification. See Reha Poroy/Ünal Tekinalp/Ersin Çamoğlu, Ortaklıklar Hukuku, vol. 2, 13th ed., 2017, para. 1562c; Nuri Erdem, Anonim Ortaklığın Haklı Sebeple Feshi, 2012, p. 178.

54 Yıldırım (fn. 35), p. 64; Özlem İlbasmış Hızlısoy, Anonim Şirketin Haklı Sebeple Feshi, 2016, p. 236-237.

55 Şabin (fn. 35), p. 373.

56 Yargitay (TCA), 11. Civil Division, 15 February 2011, Case No. 2009/3257, Decision No. 2011/1675 (https://www.lexpera.com.tr, last accessed 14 May 2019).

57 For detailed information on judicial review of arbitral awards under Turkish law, see Akincl (fn. 7), p. 251-261. 
within the scope of law of persons as well as corporate dissolutions, in that a judgment in relation to invalidity of a general assembly resolution directly determines the structure of the company in question. For instance, general assembly resolutions regarding amendment of the articles of association, capital increase or change of the field of activity are also closely connected with the law of persons as they make structural changes within the legal entity, but still deemed arbitrable by the same author. ${ }^{58}$ Finally, the view distinguishing between voluntary and involuntary corporate dissolutions appears to be ignoring the fact that declaratory actions can also be submitted to arbitration. Even if a company is dissolved ipso jure - for instance, in the event of the realization of a cause of dissolution stipulated in the AoA - shareholders may request a declaratory judgment from the arbitration tribunal.

While disputes related to corporate dissolution are arbitrable, certain types of dissolution requests may pose practical challenges due to the magnitude of remedial power granted to judges by law. While the claims for declaratory judgment with respect to the ipso jure dissolution of a company can be resolved by arbitration, the requests for judicial dissolution may include certain practical hurdles. Upon acceptance of the case, arbitral process may require interference of local courts in order to manage the liquidation process, to enforce interim measure ${ }^{59}$ or an alternative solution "appropriate for the case" ${ }^{60}$

\section{Case Law}

In 1983, the TCA upheld a decision that a dispute between a company and its shareholders over the request for registration in the stock ledger can be resolved by arbitration. ${ }^{61}$ The claimants - successors of a deceased shareholder - requested that the board of directors register them in the stock ledger. However, the board refused this request. The court of first instance held that the dispute must be resolved before an arbitral tribunal, established in accordance with the arbitration clause provided in the AoA of the company in question, and the TCA approved this decision.

Similarly, in a judgment dated 2010, it was affirmed by the TCA that the claim for company damages (derivative action) brought by members of a limited lia-

58 Ayoğlu (fn. 3), p. 108-118.

59 Akıncl (fn. 7), p. 134-140.

60 Art. 531 Turkish Commercial Code allows -and orders- the court to preferably adopt an alternative solution "appropriate for the case" in lieu of corporate dissolution.

61 Yargitay (TCA), 11. Civil Division, 7 April 1983, 1983/1595-1780 (https://www.kazanci.com, last accessed 10 August 2018). 
bility company ${ }^{62}$ against directors could be arbitrated, by virtue of the arbitration clause stipulated in the AoA. ${ }^{63}$ The TCA, however, refused the request for arbitration on the grounds that the arbitration clause in question could not be enforced against the directors who were not members of the company, and that severance of actions was not possible. The arbitration clause provided that "disputes among members or between members and the company shall be resolved by arbitration, and Civil Procedure Code No. 1086 shall apply to the selection of arbitrators as well as other issues regarding the settling of the dispute." (author's translation). Therefore, the TCA accepted the validity of the arbitration clause in the AoA and solely recognized its binding nature vis-à-vis the directors who held shares in the relevant company. The TCA also stated that the arbitration clause in the AoA would not bind the directors who were not members of the company, unless they conclude a written arbitration agreement. However, considering the wording of the arbitration clause in question, the scope of the clause merely included the disputes among shareholders and between shareholders and the company. It follows that the directors of the company were, in fact, not bound by the arbitration clause in their capacity as director even though they held shares in the company. Moreover, although the judgment concerns limited liability companies, there is neither a statutory rule nor a principle that requires reaching a different conclusion for joint stock companies.

In a subsequent judgment in 2012, the TCA ruled that arbitration is not possible for annulment of general assembly resolutions. ${ }^{64}$ Although the judgment involves quite a generic statement, that "a provision regarding arbitration in the AoA or an arbitration agreement is null and void", this expression should be understood as exclusive to disputes concerning the annulment of general assembly resolutions. The reasoning of the decision clearly reveals that the TCA conducted an examination only in terms of such a remedy, since all the arguments shown in the decision solely relate to this subject. The TCA held that this matter cannot be resolved between the parties by way of settlement. Furthermore, it considered that the local court - at the registered office of the company in question - specified by law, has exclusive jurisdiction. ${ }^{65}$ Finally, the TCA declared that the consolidation of actions conceptually conflicts with arbitration. As the above-mentioned arguments of the court and legal provisi-

62 Private company/Société à responsabilité limitée/Gesellschaft mit beschränkter Haftung (“GmbH”).

63 Yargitay (TCA), 11. Civil Division, 15 February 2010, Case No. 2008/9429, Decision No. 2010/1648 (https://www.lexpera.com.tr, last accessed 14 May 2019).

64 Yargitay (TCA), 11. Civil Division, 5 December 2012, Case No. 2011/13485, Decision No. 2012/19915, (https://www.lexpera.com.tr, last accessed 14 May 2019).

65 In the former Art. 382/1 TCC (currently Art. 445 TCC). 
ons are exclusively related to the annulment of general assembly resolutions, the TCA's approach should be understood within the limits of its purpose.

In 2014, the TCA ruled for the invalidity of an arbitration agreement concerning corporate dissolution for lack of mandatory organs and dissolution for just causes. ${ }^{66}$ Although the arbitration clause in question was included in an SHA, the same conclusion can be reached for those provided in the AoA, since the judgment was justified on the non-arbitrability argument. The court held that the subject matter of the dispute could not be freely disposed by way of settlement, and that the local court designated by law had exclusive jurisdiction. Having said that, the court's statement that "an arbitration clause in an agreement or an arbitration agreement among the shareholders is null and void" should, again, be understood as exclusive to disputes regarding corporate dissolution. This is because the TCA conducted an examination only in terms of the remedies pursuant to TCC Articles 530 and 531, and confined its justifications to these claims by expressly articulating these statutory provisions.

\section{Current Position of Turkish Law}

Under Turkish law, corporate law disputes are, in principle, considered arbitrable, whereas disputes concerning the validity of corporate decisions, as well as actions for dissolution, are still debated. It seems that the TCA has so far followed the distinction adopted by the doctrine in general terms and has not yet allowed the arbitration of disputes regarding the annulment of general assembly resolutions and actions for dissolution. Yet, one cannot ignore the growing proarbitration tendency in Turkish legal doctrine, in parallel with many other jurisdictions. ${ }^{67}$ In particular, the arbitrability of disputes regarding the validity of corporate decisions is increasingly supported in legal doctrine; hence, it would not be surprising if the TCA were to eventually follow this approach, as it alrea$\mathrm{dy}$ has for derivative claims and requests for registration in the stock ledger.

\section{E. Place of the Arbitration Clause: AoA or SHA?}

Due to uncertainties regarding the validity of the arbitration clauses stipulated in the AoAs of joint stock companies, it is frequently observed in practice that a separate agreement is concluded amongst shareholders, and an arbitration

66 Yargitay (TCA), 11. Civil Division, 9 April 2014, 2014/141-6951 (https://www.lexpera. com.tr, last accessed 14 May 2019).

67 Born (fn. 10), p. 1028-1031; Viscasillas (fn. 9), para. 14-18-14-33. For various examples of legislative reforms towards expanding the scope of arbitration, see Section ' $C$ '. 
clause is incorporated therein. Yet, instead of offering a solution, this further complicates the problem. This is so because only contractual claims can be raised in arbitral proceedings carried out in accordance with SHAs, whereas it is typically not possible to prevent claims peculiar to corporate law from being asserted in national courts. Thus, contradicting judgments may be given in these parallel proceedings. ${ }^{68}$

Furthermore, the binding effect of the provisions of AoAs differs from that of the arrangements provided in SHAs. The AoA binds (organs of) the company, its board members, and all its shareholders, regardless of whether they have actually consented or not. Meanwhile, the SHA is not binding vis-à-vis third parties, namely, non-signatory shareholders, directors or the company. In turn, this would lead to a fragmentation of claims, in that the arbitral tribunal would deal with the claims amongst the parties to the SHA, whereas the remaining stakeholders' claims would have to be addressed by the local courts.

In order to avoid these problems and to enable the agreed mechanisms on the corporate level as well, it is necessary to provide an arbitration clause in the AoAs of companies. In fact, trade registries are responsible for examining whether an AoA includes any provision contrary to the mandatory legal norms of the TCC. ${ }^{69}$ The registry has the authority to reject a request for registration, in the event that a provision of the (draft) AoA violates the TCC. However, in practice, this administrative inspection cannot be conducted effectively, and the validity of an arbitration clause stipulated in an AoA that has been registered and published remains uncertain until a court decision or arbitral award is rendered as to this question. Unlike in German law, registration at the trade registry has no remedial effect in Turkish law, and thus, registration of the AoA does not validate its provisions which contravene the TCC.$^{70}$ Clarifying the standpoint of Turkish law with regard to the validity of an arbitration clause stipulated in the AoA of joint stock companies would therefore contribute to legal predictability.

\section{F. Validity of Arbitration Clause Provided in the AoA}

Pursuant to IAC Article $4 / 3^{71}$, Turkish law applies to the validity of an arbitration agreement, unless otherwise agreed upon by the parties. An arbitration

68 Olivier Bloch, Les Conventions d'Actionnaires et le Droit de la Société Anonyme, 2006, p. 371-372.

69 Art. 32/2 TCC.

70 For German law, see $\mathbb{} 242$ German Stock Corporation Act.

71 "The validity of the arbitration agreement is subject to the law chosen by the parties or, in the absence of such choice, according to Turkish Law." (author's translation). 
agreement may be concluded as a separate agreement, or the parties may insert an arbitration clause in their actual agreement. Therefore, an arbitration agreement is based on the parties' consent to arbitration. Moreover, an arbitration agreement is only valid if concluded in writing. ${ }^{72}$ Hence, following the arbitrability issue, the validity of an arbitration clause stipulated in an AoA should be examined in terms of 'consent to arbitration' and the 'written form requirement'.

\section{Consent to Arbitration}

\section{Legal Nature of the AoA}

An analysis of 'consent to arbitration' with respect to arbitration clauses provided in the AoA accommodates certain particularities, compared to arbitration agreements or arbitration clauses in commercial agreements based on the law of obligations. This is because the AoA of joint stock companies exhibit characteristics distinct from agreements, such as sale, loan or share purchase agreements. While ordinary agreements are subject to a wide contractual freedom, formed by the mutual expression of intent, and deemed binding only among the parties, the AoA differs in respect to these points. Hence, the study discusses the concerns related to the below-mentioned characteristics of the AoA.

Firstly, agreements based on the law of obligations only bind the parties to the relevant agreement, and are thus subject to the rule of privity of contract. Likewise, an AoA entails contractual rights and obligations only among the founders of a company, until its registration at the relevant trade registry. ${ }^{73}$ As of registration, however, it attains the features of a statutory norm, thus acquiring an extended binding effect like that of objective legal norms. It follows that the AoA becomes binding over the company, its board members and those who enter the company by share acquisition, as well as the company's founders. ${ }^{74}$ The AoA is, therefore, referred to as the 'constitution' of a company

72 For domestic and international arbitration, respectively, in Art. 412/3 CPC and Art. 4/2 IAC.

73 A company is deemed incorporated with the registration of the AoA (Art. 355/1 TCC).

74 Erdoğan Moroğlu, Anonim Ortaklık Anasözleşmesi ve Hukuki Niteliği, in: Nami Barlas et al. (ed.), Prof. Dr. M.Kemal Oğuzman'ın Anısına Armağan,, p. 515-529, 515; Babtiyar, Anasözleşme (fn. 14), p. 30-31. The provisions listed in para. (a)-(h) of Art. 354 Turkish Commercial Code benefit from the positive effect of registration at the trade registry and, consequently, even bind third parties. 
(Organisationsverfassung) $)^{75}$ or its 'social pact' (pacte social). ${ }^{76}$ Yet the contractual nature of the AoA does not disappear with the registration of the company, but only fades into the background with the emergence of statutory features. Indeed, the AoA is considered a contract of adhesion (contrat d'adbésion). ${ }^{77}$ Therefore, the AoA has a dual nature as of registration: statutory (like objective legal norms) and contractual (like ordinary agreements). ${ }^{78}$

Secondly, all shareholders are bound by the amendments of the AoA, even if they did not vote in favour of the amendment in question in the relevant general assembly meeting. ${ }^{79}$ Accordingly, the majority rule applicable in corporate law allows the insertion of provisions in the AoA without a unanimous vote, unless otherwise specified in the AoA, and replaces the mutual expression of intent sought in ordinary contract formation.

Finally, while ordinary agreements are mainly regulated by the default rules of the law of obligations, and are hence subject to the principle of contractual freedom, the AoA is largely governed by mandatory norms. Furthermore, the TCC adopted the principle of mandatory norms, the so-called Satzungsstren$g e$, which further curtailed the already limited freedom within the AoA of joint stock companies. ${ }^{80}$

75 Arnd Arnold, in: Wolfgang Zöllner/Ulrich Noack (ed.), Kölner Kommentar zum Aktiengesetz, vol. 1, 3rd ed., $2011 \rrbracket 23 \mathrm{mn}$. 8. Moreover, it is described as an 'organizational agreement' (Organisationsvertrag) or 'foundation agreement' (Gründungsvertrag) in order to emphasize its difference from ordinary reciprocal contracts, in that a legal personality apart from the parties appears as a result of the conclusion of the AoA, Völker Röbricht/Alexander Schall, in: Heribert Hirte/Peter O. Mülbert/Markus Roth (ed.), Großkommentar Aktiengesetz, vol. 2/1, 5th ed., 2016, $\$ 23 \mathrm{mn} .63$.

76 For French law, see Daniel Cohen, Arbitrage et Société, 1993, p. 67. For a detailed analysis of case law regarding the discussion of the AoA's legal nature in English law, see Sarab Worthington, Sealy and Worthington's Text, Cases and Materials in Company Law,11th ed., 2016, p. 261-271. The AoA is referred to as an "agreement inter socios" in Eley $v$ The Positive Government Security Life Assurance Co Ltd (1876) 1 Ex. D. 88 (Court of Appeal), p. 90.

77 Moroğlu (fn. 74), p. 515. "Contract of adhesion", also called as "standard form contract", is a contract drafted by one party, who generally has stronger bargaining power, and signed by another party with weaker bargaining power. Therefore, these types of contract are sometimes referred to as "take-it-or-leave-it" contracts.

78 Röhricht/Schall (fn. 75), $\$ 23$ mn. 11; Andreas Pentz, in: Wulf Goette/Mathias Habersack/Susanne Kalss (ed.), Münchener Kommentar zum Aktiengesetz, vol. 1, 4th ed., 2016, $\$ 23 \mathrm{mn} .10$; Arnold (fn. 75), $\$ 23 \mathrm{mn} .9$.

79 Art. 423 TCC.

80 For a detailed explanation of the principle of mandatory norms (Satzungsstrenge), see Subsection 'F.I.3.b'. 


\section{Distinction between the Corporative and Formal Provisions of the AoA}

The peculiar legal nature, and particularly the extended binding effect conferred upon the provisions of AoA play a pivotal role in the assessment of consent to arbitration in regard to an arbitration clause stipulated in the AoA. Yet, although the whole text of the AoA is registered at the trade registry, not all its provisions acquire such an extended binding effect. This is because certain provisions elude the control mechanism conducted by trade registries, even though they are, in fact, either not allowed by corporate law or do not relate to intra-corporate issues. These are referred to as 'formal' (contractual, nichtkorporativ) provisions of the AoA and are devoid of the extended binding effect, albeit provided in the text of the AoA. Therefore, these are deemed purely contractual in nature and can only be enforced among the parties in just the same way as the provisions of an SHA. ${ }^{81}$

On the other hand, 'corporative' (substantial, korporativ) provisions relate to intra-corporate issues and comply with corporate law. Therefore, corporative provisions of the AoA are endowed with the extended binding effect. For example, provisions establishing the right to buy/sell shares among shareholders (call/put options) are deemed 'formal' in nature, since the AoA cannot incur any further obligations upon shareholders other than their capital commitment. ${ }^{82}$ But these undertakings can be enforced among the parties as purely contractual provisions. Another example is voting agreements between shareholders: it is undisputed that while shareholders can undertake to vote in a certain direction at general meetings, such commitments stipulated in an AoA are not enforceable at the corporate level. In the event that a shareholder violates her commitment, the counterparties cannot invalidate her vote. On the contrary, the required quorums at general meetings for significant resolutions may be increased in the AoA, as long as doing so is permitted by the relevant corporate law rules. ${ }^{83}$ These quorum requirements are considered to be 'corporative', and hence any resolution purportedly passed at an inquorate meeting is deemed null.

Accordingly, the question of whether the parties to a dispute are bound by the arbitration clause in the AoA primarily depends on the legal nature of the provision in question. ${ }^{84}$ As further discussed below in Subsection 'F.I.4' if the ar-

81 For Turkish law, see Moroğlu (fn. 74), p. 525; Babtiyar (fn. 34), p. 235-238; Gül Okutan Nilsson, Anonim Ortaklıklarda Paysahipleri Sözleşmeleri, 2004, p. 101-104. For German law, see Röhricht/Schall (fn. 75), $\$ 23$ mn. 15; Pentz (fn. 78), $\$ 23$ mn. 39-42; Koch (fn. 12), \ $23 \mathrm{mn} .3-4$.

82 Art. 480 TCC.

83 General assembly quorum requirements are mainly regulated in Articles 418 and 421 TCC.

84 Büchler/von der Crone (fn. 19), p. 261. 
bitration clause in the AoA is considered corporative in nature, then it binds the company, its board members, those shareholders who acquired their shares after the insertion of an arbitration clause into the AoA (new shareholders), and the current shareholders as well. In contrast, if the arbitration clause in the AoA is deemed a formal provision, then only the parties who have actually consented to that provision are bound by it. This duality of corporative and formal provisions requires the identification of the legal nature of the arbitration clause stipulated in the AoA. However, this is a significantly complicated task, since there is no statutory rule in the TCC as to whether the AoA may include an arbitration clause or not. ${ }^{85}$ Although several criteria are suggested to qualify corporative and formal provisions, none of them are generally accepted. ${ }^{86}$

In my view, a two-step test should be applied so as to distinguish corporative provisions from formal ones. In the first stage, the arbitration clause in the AoA should be analyzed to understand whether it is intended to bind the company, the board members (optional), and new shareholders, as well as the current shareholders. If the scope of the provision includes such a broad circle of stakeholders, it means the provision is intended to operate on the corporate level. Otherwise, the provision in question would be deemed a formal one, and there would be no need to proceed with the second step of the test. However, even if the provision passes the first step, it does not necessarily mean that the provision acquires corporative nature. It must still be examined, in the second stage, to determine whether the rules of corporate law applicable to the company in question allow for an arbitration clause in the AoA. While the first question relates to the interpretation of the arbitration clause in the AoA, the second question requires determining the scope of contractual freedom within the AoA of joint stock companies in Turkish corporate law.

\section{Contractual Freedom within the AoA}

\section{a) The Principle of Sole Obligation}

Contractual freedom in joint stock company law is much more restricted, compared to agreements based on the law of obligations. The principle of sole obligation of shareholders vis-à-vis the company (la responsabilité limité inter-

85 The preamble of TCC Art. 561, which designates the competent court for derivative actions for a company's loss, explicitly indicates that an arbitration agreement may be concluded for such claims. However, the preamble of the relevant article is not binding when applying and interpreting the article.

86 For the criteria suggested in doctrine see Okutan Nilsson (fn. 81), p. 95-100 and the authors mentioned therein. 
ne/beschränkte Haftung des Aktionärs nach innen), which is enshrined in TCC Article 480/1, may be considered a potential barrier against stipulating an arbitration clause in the AoA.$^{87}$ According to the principle, no liabilities other than payment of the subscribed capital and share premium (if applicable) can be imposed on shareholders in joint stock companies by means of the AoA. Therefore, if the requirement of referring to arbitration is seen as an 'obligation' in terms of the TCC Article 480/1, then providing an arbitration clause in the AoA cannot be permitted and, thus, can only be considered a formal provision.

Swiss law, which includes the same provision in the Obligationenrecht (Swiss Code of Obligations) (SCO) Article 680/1, does not consider the principle a barrier because being obliged to refer to arbitration is not seen as an additional obligation. ${ }^{88}$ This is so because being referred to arbitration does not affect the substantive rights and obligations of shareholders. This view is accepted with similar reasons in French law. ${ }^{89} \mathrm{In}$ my view, there is no reason inherent in Turkish law that would require a deviation from the approach adopted in Swiss and French law, since the arbitration clause in the AoA does not impose an additional obligation upon shareholders within the meaning of TCC Article 480/1.

\section{b) The Principle of Mandatory Norms (Satzungsstrenge)}

With the enactment of the TCC in 2012, the principle of mandatory norms (Satzungsstrenge) enshrined in TCC Article 340 was introduced into the Turkish legal system from $\mathbb{2 3 / 5}$ of the German Stock Corporation Act. TCC Article 340 reads as: "The articles of association may diverge from the provisions of this Code relevant to joint stock companies only if expressly allowed in this Code. The supplementary provisions of articles of association allowed to be stipulated by other codes shall be effective specifically for the relevant code." (authors translation). The principle further narrowed down the limits of contractual freedom within the AoA of joint stock companies, as it allows the AoA to deviate from the law only in cases where it is explicitly permitted by the TCC to do so. This means that the provisions of the TCC concerning joint stock companies are, in principle, mandatory.

87 The principle is distinguished from the limited liability of shareholders against corporate creditors (la responsabilité limité externe/beschränkte Haftung des Aktionärs nach außen), see Otto Meyer, Des Versements Supplémentaires des Actionnaires, 1935, p. 58; Werner Naegeli, Der Grundsatz der beschränkten Beitragspflicht, insbesondere der Ausschluss der Nachschlusspflict im Aktienrecht,1948, p. 23.

88 See text to fn. 19.

89 Coben (fn. 76), p. 191. 
The principle's scope of application differs greatly depending upon the way TCC Article 340 is interpreted. On the one hand, the liberal approach advocates that an "explicit permission" is sought only in terms of the issues already regulated by the TCC 90 . This view focuses on the term "deviate from" and argues that in the absence of a statutory norm, there is no rule to deviate from. This means that the AoA may freely prescribe provisions on matters not regulated by the TCC. On the other hand, if the principle is interpreted in a strict way, a provision in an AoA on any issue that is not regulated by the TCC would constitute a deviation from the law. ${ }^{91}$ Furthermore, the strict view seeks "explicit permission" in the wording of the relevant statutory rule. ${ }^{92}$ Therefore, one cannot stipulate a provision in the AoA, unless the TCC explicitly permits doing so with expressions such as "unless otherwise provided in the AoA", "the AoA may provide differently", etc. However, the permissive approach argues that the ratio legis of the relevant provision must also be considered while determining whether the TCC explicitly permits the AoA to deviate from the law. ${ }^{93}$

Since there is no provision in the TCC with respect to the inclusion of an arbitration clause in the AoA of joint stock companies, or with respect to arbitration in general, an arbitration clause cannot be provided in the AoA if the strict approach is to be followed. For instance, an arbitration clause concerning disputes related to the controlling company's right to purchase minority shares pursuant to TCC Article 208 would not be permitted, although the dispute is in fact arbitrable.

In 2015, the TCA delivered a judgment with respect to the interpretation of Satzunggstrenge, where it stated that an AoA may introduce the requirement

90 Karasu (fn. 35), p. 57; İsmail Kırca/Feyzan Hayal Şehirali Çelik/Çağlar Manavgat, Anonim Şirketler Hukuku, vol 1, Temel Kavram ve İlkeler, Kuruluş, Yönetim Kurulu, 2013, p. 158; Hasan Pulaşl, Şirketler Hukuku Genel Esaslar, $5^{\text {th }}$ ed., 2017, p. 285. In German law see Ernts Geßler, Bedeutungund Auslegung des $\$ 24$ Abs. 5 AktG, in: Ottoarndt Glossner/Walter Reimers (ed.), Festschrift für Martin Luther zum 70. Geburtstag, 1976, 73-74; Martin Luther, $\ 23$ Abs. 5 AktG im Spannungsfeşd von Gesetz, Satzung und Einzelentscheidungen der Organe der Aktiengesellschaft, in: Wolfgang Bernhardt/Wolfgang Hefermehl/Wolfgang Schilling, Freundesgabe für Hans Hengeler für 70. Geburtstag, 1972, p. 171; Röbricht/Schall (fn. 75), $\$ 23$ mn. 176. Cf. Arnold (fn. 75), \ $23 \mathrm{mn} .137$.

91 Mebmet Babtiyar, Ortaklıklar Hukuku, 13 ${ }^{\text {th }}$ ed., 2019, p. 131.

92 Kırca/Şebirali Çelik/Manavgat (fn. 90), p. 160-161; Babtiyar, Ortaklıklar (fn. 91), p. 131.

93 Karasu (fn.3), p. 50-52; Oruç Hami Şener, Teorik ve Uygulamalı Ortaklıklar Hukuku Ders Kitab1, 2012, p. 298; Fatih Bilgili/Ertan Demirkapı, Şirketler Hukuku, 2013, p. 233-234; Pulaşlı (fn. 90), p. 285; Ayoğlu (fn. 3), p. 28. For German law see Luther (fn. 90), p. 171-172; Geßler (fn. 90), p. 72; Pentz (fn. 78), $\$ 23$ mn. 161; Röbricht/Schall (fn. 75), $\$ 23$ mn. 178; Arnold (fn. 75), $\$ 23$ mn. 139. 
of holding shares in the company as an eligibility criterion to be elected a member of the board of directors. ${ }^{94}$ The TCA stated in said decision that TCC Article 359 , which regulates the eligibility requirements of board members, is not 'conclusive', hence, 'complementary' provisions may be stipulated in the AoA. However, the decision does not pertain to a 'deviation' from law, but to 'completion' thereof. Besides, the TCA has not yet addressed the issue of whether stipulating a provision in the AoA on a subject that is not regulated by the TCC would constitute a deviation from the law. Therefore, the question of whether an arbitration clause provided in the AoA violates the principle of mandatory norms has not yet been resolved.

In my view, however, the principle of mandatory norms should not be interpreted so as to undermine the development of joint stock company law. Since the TCC cannot prescribe a rule for every kind of mechanism that shareholders may establish, an AoA should be able to comprise provisions on subjects that are not covered by the TCC. Moreover, there are three types of provisions in the TCC; (i) provisions that explicitly forbid the AoA to deviate from the law, (ii) provisions that explicitly permit stipulating otherwise in the AoA and (iii) provisions that are silent on whether the AoA may regulate a subject different than the TCC. ${ }^{95}$ The wording of the statutory rules in the third group neither permits nor forbids the stipulation of a provision in the AoA in a manner different from the TCC. Hence, the ratio legis of these provisions should also be taken into consideration while determining whether the TCC 'explicitly permits' the AoA to deviate from the law. Furthermore, the preamble of TCC Article 340 clearly supports this view. The relevant part of the preamble reads as:

\footnotetext{
“The expression 'if expressly allowed in this code' also includes the assumptions where a 'deviation' can be justified by an interpretation that is fit for the purpose, not contrary to the methodology doctrine, based on convincing reasons, having fair consequences and paying regard to the balance of interests, in the event that the possibility to 'deviate' is not expressly understood from the wording of the relevant provision. (author's translation)." ${ }^{\text {' } 6}$
}

While this approach can be adopted for privately held joint stock companies, the principle may be interpreted in a stricter way for publicly traded companies. This is because it would be more challenging to force small investors in

94 Yargitay (TCA), 11 CD, 7 July 2015, Case No. 2014/15813, Decision No. 2015/8851, <https://www.lexpera.com.tr> accessed 14 May 2019.

95 For (i), see TCC Articles 348/1 and 416/2; for (ii), see TCC Articles 362/1 and 366/1; for (iii), see TCC Art. 531.

96 The preamble can be found at <www2.tbmm.gov.tr/d22/1/1-1138.pdf $>$ accessed $10 \mathrm{Au}-$ gust 2018 . 
capital markets, who are already devoid of contractual freedom to negotiate the AoA, to refer to arbitration. ${ }^{97}$

\section{Binding Effect of Arbitration Clauses Provided in the AoA}

In light of the above observations, it is concluded that there is no rule or principle in Turkish corporate law that restricts contractual freedom within the AoA of privately held joint stock companies so as to restrain arbitration clauses. ${ }^{98}$ Neither the principle of sole obligation nor the principle of mandatory norms prevents the insertion of an arbitration clause in an AoA. ${ }^{99}$ This finding plays a key role in the second step of the test suggested by this study for the identification of corporative provisions. Therefore, unless the arbitration clause in question is intended only to bind the current shareholders at the time of incorporation or the related amendment, it is deemed a corporative provision of the $\mathrm{AoA}^{100}$.

An arbitration clause can therefore be provided either in the original AoA, or by way of an amendment thereof. Since the original AoA is signed by each founder, there is not a problem of consent at the outset. In the event that such a provision is inserted in the AoA via an amendment, a unanimous vote must be sought. ${ }^{101}$

97 Towards a more liberal interpretation of Satzungsstrenge in privately held companies, see Bayer (fn. 16), p. 126-129; Klaus J. Hopt, "Gestaltungsfreiheit im Gesellschaftsrecht in Europa - General Bericht-”, Zeitschrift für Unternehmens- und Gesellschaftsrecht - Sonderheft 1998, 123, 144; Peter Hommelhoff, Satzungsstrenge und Gestaltungsfreiheit in der Europäischen Aktiengesellschaft, in: Mathias Habersack et al. (ed.), Festschrift für Peter Ulmer, 2003, p. 271. For more liberal views asserted in English and Swiss laws, see Elliott Geisinger/Sinem Mermer, Arbitral Clauses in Articles of Association or By-Laws of Legal Entities in: Ziya Akınc1/Candan Yasan-Tepetaş (ed.), Şirketler Hukuku Uyuşmazlıkları ve Tahkim, 2018, p. 52-55.

98 It must be reiterated here that the arbitrability of a dispute and the validity of an arbitration clause are different questions.

$99 \operatorname{Karasu}$ (fn. 35), p. 173; Ayoğlu (fn. 3), p. 30-35.

100 It must be noted here that the TCA considers the disputes over invalidity of general assembly resolutions and corporate dissolutions inarbitrable. It means that an arbitral clause would be ineffective in terms of such disputes, regardless of whether it is accepted as a corporative or formal provision of the AoA (see text to fn. 64 and 66).

101 Poroy/Tekinalp/Çamoğlu (fn. 34), para. 731; Kaya (fn. 34), p. 2001, 332; Huysal (fn. 3), p. 296; Ayoğlu (fn. 3), p. 45-46. Ayoğlu asserts that an arbitration clause in the AoA can only be of a formal nature. In my view, requiring unanimous vote for inserting an arbitration clause in the AoA does not conflict with the view that such an arbitration clause is of corporative nature. The quorum required for a certain resolution does not automatically determine its legal nature. A general assembly resolution may require unanimous vote, but can still be of a corporative nature. Once accepted unanimously, the said resolution would bind the new shareholders and the company, as well as the 
This is because the jurisdiction of an arbitral tribunal is justified by the consent of the parties to arbitration. Therefore, requiring a quorum less than unanimity would lead to forcing the opposing shareholders to refer to arbitration.

Once inserted in the AoA, however, the company ${ }^{102}$, the board members ${ }^{103}$, the new shareholders, and the current shareholders are bound by the corporative arbitration clause. ${ }^{104}$ At this point, one may argue that shareholders who enter a company after the insertion of an arbitration agreement might not have consented to the arbitration clause in the AoA. Due to the extended binding effect conferred upon the terms of the AoA, there is no need for an additional inquiry for actual consent to arbitration. In fact, corporative provisions of the AoA bind shareholders in their capacity as shareholder because rights and obligations arising from the AoA are attached to the status of shareholder, rather than to the shareholders in person. ${ }^{105}$ The corporative nature of the arbitration clause does not conflict with the fact that arbitration is based upon consent. Shareholders' intent to establish or join into a company constitutes the contractual basis underlying the binding effect of corporative terms. ${ }^{106}$ This means that, although the extended binding nature of the AoA is conferred by the TCC, it takes its source

current shareholders. For instance, TCC Art. 421 requires unanimous vote for moving the registered office to a foreign country; but it is obvious that this is a corporative provision of the AoA. Thus, an arbitration clause inserted in the AoA by unanimous vote binds the new shareholders and the company as well as the current shareholders.

102 The company's consent to arbitration is expressed in the original version of the AoA or the general assembly resolution regarding the amendment thereof.

103 In the event that the scope ratione personae of the arbitration clause in question includes the board members, they are to be bound by the arbitration clause, provided that they have consented to being appointed a member of the board after the stipulation of such a clause in the AoA. Unlike shareholders, they do not have voting rights in the general assembly meetings so as to veto the proposed amendment of the AoA.

104 For German law see Duve/Wimalasena (fn. 16), p. 936. For Swiss law see Büchler/von der Crone (fn. 19), 261; Kaufmann-Kobler/Rigozzi (fn. 17), para. 3.90. For Turkish law see Helvacı (fn. 34), p. 190; Babtiyar (fn. 34), p. 211; Huysal (fn. 3), p. 296. Cf. Ayoğlu (fn. 3), p. 69-70, also see fn. 101 and 110.

105 In parallel with English law, as accepted in Hickman $v$ Kent or Romney Marsh SheepBreeders' Association [1915] 1 Ch 881 (High Court). Obligations related to a specific status are conceptualized under the term "Zustandsobligationen", "obligations' d'état", Şafak Erel, Eşyaya Bağl1 Borç, 1982, p. 51; Rona Serozan, Medeni Hukuk Genel Bölüm Kişiler Hukuku, 7th ed., 2017, p. 247). Hence, rights and obligations attached to the shares of the company are transferred ipso jure to the new shareholder with the transfer of shares.

106 Legal relationships based on share ownership within companies having legal personality differ from ownership of rights arising directly from the law, see Nami Barlas, Adi Ortaklık Temeline Dayalı Sözleşme İlişkileri, 4th ed., 2016, p. 59-60. Transfer of rights and obligations attached to joint stock company shares derives from contractual freedom. Shareholders' intent to form or join into a joint stock company, a legal entity 
from the shareholders' consent to establish the company or to acquire its shares. Moreover, the trade registry is public and accessible to everyone. The share acquirer is available to inspect the content of the AoA of the company she is willing to join. ${ }^{107}$ Furthermore, the dual nature (contractual and statutory) of the AoA also supports this view. Since the AoA is considered an adhesion contract, a person who enters a company by acquiring its shares becomes a party to the AoA, and thus to the arbitration clause provided therein.

In the event that the arbitration clause in question is deemed a formal provision of the AoA, it may still remain effective under the law of obligations and enforceable among the parties as a purely contractual term. The shareholders' consent to arbitration should be sought according to a variety of possibilities. It is obvious that, having signed the AoA, the founders are bound by the arbitration clause until the shareholding structure changes. The assumption that the founders are still bound by the arbitration clause, while the new shareholders are not, would be incompatible with corporate law. As to the new shareholders, this is a typical case of successio singularis: if the buyer has no explicit consent to arbitration, her implied intent should be sought at the processes of due diligence and negotiation, prior to share acquisition. ${ }^{108}$ In case a 'formal' arbitration clause is provided by way of an amendment of the AoA, even the shareholders who voted for the amendment would not be bound by the clause, unless the amendment is accepted with unanimity. ${ }^{109}$ Yet the company and the

based upon the majority rule, originates from the shareholder's free will within the freedom of choosing a legal form.

107 Ticaret Sicili Yönetmeliği (Trade Registry Regulation) No. 2012/4093 Art. 15/1.

108 Esen suggests, regardless of the legal nature of the arbitration clause, that the share acquirer should have an express or implied intent towards the arbitration clause, see Emre Esen, Uluslararası Ticarî Tahkimde Tahkim Anlaşmasının Üçüncü Kişilere Teşmili, 2008, p. 136 and p. 173. Huysal, on the other hand, argues that the arbitration clause in the AoA carries the positive effect of registration at the trade registry, and thus even binds the new shareholders, see Huysal (fn. 3), p. 297. Firstly, only the provisions listed in para. (a)-(h) of Art. 354 Turkish Commercial Code benefit from the positive effect of registration, but the arbitration clause is not included therein. Secondly, these contrasting approaches ignore the distinction between the corporative and formal provisions of the AoA. Indeed, the question of whether the new shareholders are bound by formal arbitration clauses should be addressed within the frame of successio singularis, whereas the extended binding effect is to be considered in terms of arbitration clauses corporative in nature.

109 The general assembly resolution that has purportedly amended the AoA would be deemed 'non-existent', so there will be no legal act that can be considered a 'formal' provision among the parties. In addition, shareholders, having voted for the proposed amendment of the AoA, declare their consent to arbitration assuming in principle that such an arbitration clause can be enforced against all shareholders and the company. In contrast, the fact that some shareholders are bound by the arbitration clause while ot- 
board members are not bound per se by such an arbitration clause because the provision would operate as a purely contractual term and not be a part of the 'constitution' of the company. ${ }^{110}$

\section{Written Form Requirement}

An arbitration agreement is only valid if concluded in writing. ${ }^{111}$ However, an AoA is only signed by the founders prior to registration. The question is: should the written form requirement be satisfied by persons apart from the founders? In German and Swiss law, it is only sought while concluding the arbitration agreement at the outset. ${ }^{112}$ The scope ratione personae of an existing arbitration clause is, therefore, a matter of consent, which should be addressed under the law that would govern the substantive validity of the arbitration agreement. ${ }^{1{ }^{13}}$ This view is rightfully adopted in Turkish law as well. ${ }^{114}$ Since we are analyzing arbitration clauses provided in the AoA of joint stock companies incorporated in Turkey, the law applicable to the substantive validity of the arbitration clause is Turkish law, unless otherwise agreed upon by the parties. ${ }^{115}$

In the event that the arbitration clause in question is of a corporative nature, the written form requirement is deemed to have been fulfilled when the AoA is signed at the formation of the company or when the AoA is amended by a general assembly resolution. Therefore, there is no need for an additional signing of the AoA by the company or its new shareholders. However, if the written form requirement is sought even after the conclusion of the arbitration clause at the outset, the clause could not be enforced against the company or the persons who enter the company by share acquisition after the insertion of the arbitration clause. This is because neither the company nor the new shareholders actually signed the AoA. On the other hand, if the arbitration clause in

hers are not -for the same grounds of action- would be incompatible with corporate law. But cf. Ayoğlu (fn. 3), p. 69-70, who holds that the shareholders who voted for the insertion of the arbitration clause are bound by the clause.

110 Ayoğlu argues that the company is bound by the arbitration clause in the AoA (Ayoğlu (fn. 3), p. 38 and p. 61), but still notes that it can only be deemed a 'formal' provision (ibid, p. 69).

111 Art. 412/3 CPC, Art. 4/2 IAC, see also Convention Art. II/1.

$112 \operatorname{Esen}$ (fn. 108), p. 54-55.

113 Andrea Marco Steingruber, Consent in International Arbitration, 2012, para. 6.51; Kaufmann-Kobler/Rigozzi (fn. 17), para. 3.71.

114 Ercüment Erdem, Tahkim Anlaşması in: Ercüment Erdem et al., Prof. Dr. Hamdi Yasaman'a Armağan, 2017, p. 244-251; Ayoğlu (fn. 3), p. 27.

115 Art. 4/3 IAC. 
question is of a formal nature, then only the founders who signed the original AoA will be deemed to have satisfied the written form requirement.

\section{G. Conclusion and Proposals}

1. Under Turkish law corporate law disputes are, in principle, considered arbitrable, whereas disputes concerning the validity of general assembly resolutions and corporate dissolution are still debated. It seems that the case law has so far followed the distinction adopted by the orthodox doctrine in general terms. However, considering the growing pro-arbitration tendency in Turkish academic and practitioners' circles - in parallel with many other jurisdictions - it would not be surprising if a more flexible approach is eventually adopted in case law as well.

2. This paper argues that corporate law disputes are arbitrable. Moreover, it suggests that arbitral awards should be granted an erga omnes effect, as long as the interested third parties are provided with the necessary procedural protection. In order to avoid such a problem, parties can stipulate the TCC equivalent of their procedural rules in their arbitration clauses, or they can incorporate -by reference - the procedural rules set out in the TCC or the set of rules for corporate law disputes published by an arbitration institute.

3. It is necessary to provide an arbitration clause in the AoA of the company in order to (i) prevent contradicting judgments given in parallel proceedings, (ii) be able to request claims peculiar to corporate law and (iii) ensure the binding effect vis-à-vis the company, board members and new shareholders as well as the current shareholders. This paper argues that there is no rule under Turkish corporate law that restricts contractual freedom within the AoA of privately held joint stock companies so as to restrain arbitration clauses. It is also argued that an arbitration clause can be provided either in the original AoA or by way of an amendment thereof by a unanimous vote.

4. Consequently, an arbitration clause duly stipulated in the AoA is deemed corporative, unless it is intended to bind solely the current shareholders. Once inserted in the AoA, the company, the board members (optional), the new shareholders, and the current shareholders are bound by the arbitration clause. In the event that the arbitration clause in question is deemed a formal provision, it may still remain effective only among the parties as a purely contractual term. Having signed the AoA, the founders are bound by the arbitration clause until the shareholding structure changes. However, the company, the board members and the new shareholders are not bound, unless they have consented to arbitration. Moreover, an arbitration clause is valid only if concluded in writing. The written form requirement should be deemed to have been fulfilled 
when the AoA is signed at the formation of the company or when the AoA is amended by a general assembly resolution. Hence, there is no need for an additional signing of the AoA by the company or its new shareholders.

5. While keeping pace with the liberal views towards expanding the scope of arbitration in corporate law disputes, the foundational principles of corporate law cannot be renounced. Considering the main objectives of corporate law, namely, the minimization of transaction costs and the regulation of conflicts of interest among various stakeholders, one cannot argue for a purely permissive approach. Therefore, certain safeguards need to be established in order to protect minority shareholders, creditors, and other third parties. The views argued in this paper aim to strike a balance between contractual freedom in corporate law and the protection of weaker parties vis-à-vis the controlling shareholder (s) and/or the directors. Hence, interpretations of positive norms and de lege ferenda suggestions are cautiously made in this regard. Certain safeguards that would serve this end are as follows: (i) a unanimous vote should be sought while inserting an arbitration clause by way of amendment, (ii) an arbitration clause can only be stipulated in the AoA of privately held companies, (iii) the arbitration process must comply with the minimum procedural standards offered by law, particularly, the pending of the case until the term of litigation expires and the consolidation of all the actions filed before the tribunal, and (iv) arbitrators should be appointed collectively, unless selected by an impartial body. The below-mentioned recommendations aim to complete this structure.

6. Considering international developments and regulatory competition, Turkish legislators should maintain their pro-arbitration position with an openminded approach. The necessary steps recommended to increase the legal certainty of Turkish law with regard to the arbitration of corporate law disputes can be listed as follows:

i. The arbitrability of corporate law disputes and the validity of arbitration clauses stipulated in the AoAs of joint stock companies should be clarified in the TCC. Likewise, procedural standards to protect third parties' interests, as well as the erga omnes effect of arbitral awards should be regulated. Italian Legislative Decree of 17 January 2003 No. 5 Articles 34-37 and the German Federal Supreme Court decision of 6 April 2009 offer inspiring examples in this respect.

ii. The leading arbitration institutions should draft and publish supplementary rules for corporate law disputes as annexes to their existing rules of arbitration. These rules should consider the problems peculiar to corporate law disputes. Hence, they should provide such mechanisms as i) the pending and consolidation of actions filed before the arbitral tribunal, ii) collective - or impartial - selection of arbitrators so as to provide the minimum procedural protection granted to minorities in 
TCC Articles 445-451. A comprehensive example is the German Arbitration Institution's 'DIS-Supplementary Rules for Corporate Law Disputes 09'.

iii. With a view to facilitating the incorporation of applicable and valid arbitration clauses into the AoA, a model arbitration clause referring to the above-mentioned supplementary rules for corporate law disputes should be published by leading arbitration institutions. A model clause may be elaborated from the below draft model, inspired by the 'DISModel Clause for Corporate Law Disputes 09' of the German Arbitration Institution and the resolution dated 27 April 1989 of General Direction of the Registers and Notaries in Spain ${ }^{116}$ :

"All disputes arising between the shareholders or between the company and its shareholders in connection with corporate law, the articles of association and corporate decisions shall be finally settled according to $[\mathbf{\square}]^{117}$ of $[\mathbf{\square}]^{118}$ which would govern the appointment of the arbitrators ${ }^{11}$.

The Arbitral Tribunal consists of $[\mathbf{\square}]$ arbitrator(s). ${ }^{120}$ The arbitral tribunal is competent and obliged to apply the procedural rules specific to the type of the dispute as well as substantive rules provided in Turkish Commercial Code No. 6102.

\section{The place of arbitration is $[\mathbf{\square}]$.}

The language of the arbitral proceedings is [ $\mathbf{\square}]$.

The effects of an arbitral award rendered in accordance with the $[\mathbf{\square}]^{121}$ is binding for the company and all shareholders irrespective of whether they have made use of their opportunity to join the arbitral proceedings as a party or as an intervenor.

116 Viscasillas (fn. 9), para. 14-13 fn. 29. A noteworthy model clause can also be found in Ayoğlu (fn. 3), p. 169-171.

117 The title of the supplementary rules for corporate law disputes of the relevant arbitration institution. It is assumed that the procedural protection mechanisms are regulated by the supplementary rules for corporate law disputes of the relevant arbitration institution.

118 The name of the relevant arbitration institution.

119 Alternatively 'sole arbitrator'.

120 The number of arbitrators maybe left to the relevant arbitration institution, which may determine the number depending on the complexity of the dispute.

121 The title of the supplementary rules for corporate law disputes of the relevant arbitration institution. 
The corporation shall always raise the existing arbitration agreement as a defence against any claim that is filed in the ordinary courts of law and that relates to disputes in the meaning of this provision."

Acknowledgment: I wish to thank M. Fadlullah Cerrahoğlu, Zekeriya Yıldırım, Memduh Karakullukçu and Tuvan Yalım for their valuable contribution as commission members in Global Relations Forum's Young Academics Program 2017. I am grateful to Özgün Çelebi, M.Polat Kalafatoğlu, Berk Demirkol, Selin Uğurtaş and the anonymous reviewers for their helpful comments, and Abdurrahman Kayıklık and Gökçe Gül Önder for their excellent research assistance. 